\title{
LATENTNA STRUKTURA I KONVERGENTNA VALIDNOST NOVE SKALE AUTORITARNOSTI ${ }^{1}$
}

\author{
Vladimir Mihić², Bojana Bodroža i Petar Čolović \\ Odsek za psihologiju, Filozofski fakultet, Novi Sad
}

U radu su prikazane dve studije, prva namenjena proveri internih metrijskih karakteristika $i$ konstruktne validnosti nove skale za procenu autoritarnosti, UPA-S, a druga pokušaju da se doprinese odgovoru na pitanje da li je autoritarnost osobina ličnosti ili sindrom stavova. Ovaj 47ajtemski instrument predstavlja kombinaciju stavki dve skale - ADO, namenjene proceni autoritarnosti kao osobine ličnosti, i AUT-NS, koja autoritarnost tretira pre svega kao sindrom stavova. Osnovni cilj prve studije bila je provera internih metrijskih karakteristika skale UPA-S. Analizom glavnih komponenti, uz Promax rotaciju, u prostoru merenja skale UPA-S ekstrahovane su tri latentne dimenzije nazvane autoritarna submisivnost, autoritarna agresivnost i stoicizam. Skale formirane na osnovu matrice faktorskog sklopa imaju zadovoljavajuće pokazatelje pouzdanosti, homogenosti i reprezentativnosti. Konvergentna validnost skale UPA-S proverena je u okviru druge studije. Konfirmativnom faktorskom analizom testirana su tri modela latentne strukture zajedničkog prostora skala UPA-S, Altemejerove Skale desničarske autoritarnosti, Beogradske revizije F skale autoritarnosti, Skale socijalne dominacije i Skale modernog rasizma. Najadekvatnijim se pokazao model koji podrazumeva dve korelirane latentne dimenzije, od kojih prva obuhvata operacionalizacije autoritarnosti, a druga operacionalizacije srodnih koncepata. Rezultati ukazuju na zadovoljavajuća merna svojstva skale UPA-S, idu u prilog shvatanju autoritarnosti kao višedimenzionalnog konstrukta čiji sadržaj objedinjuje specifični sindrom stavova i indikatore osobina ličnosti koje se tradicionalno smatraju korelatima antidemokratske orijentacije.

Ključne reči: autoritarnost, socijalna dominacija, rasizam, F skala

\footnotetext{
${ }^{1}$ Rad je deo projekta „Psihološki aspekti društva u tranziciji“, broj 149008 koji finansira Ministarstvo nauke Republike Srbije

22E-mail autora: mihic@ff.ns.ac.yu
} 


\section{Uvod}

Autoritarnost se u sociološkoj i psihološkoj literaturi verovatno prvi put spominje u delima Eriha Froma. Problem autoritarnosti From je, međutim, tretirao pre svega spekulativno, bez adekvatne empirijske provere. Ipak, koncept autoritarne ličnosti koji su uveli Adorno i saradnici (Adorno, FrenkelBrunswik, Levinson, \& Sanford, 1950), svakako u mnogome crpi svoje premise upravo iz Fromovog rada. U Fromovom psihoanalitičkom pristupu ovoj temi ističe se presudan uticaj ranog iskustva iz porodičnog okruženja na formiranje autoritarnosti. Autoritarnost, kao centralni mehanizam bekstva od slobode u periodu raskidanja veze sa autoritetom iz ranog detinjstva (ocem), odlikuju dve tendencije: autoritarna dominacija i autoritarna submisivnost - tj. autoritarno-mazohistički karakter (Fromm, 1989/1941).

Tek tridesetak godina nakon Froma, objavljivanjem istraživanja Adorna i saradnika na temu antidemokratske orijentacije, poznatog kao Berklijska studija, ova tema dobija ključni značaj i postavlja temelje političke psihologije.

Istraživanje Adorna i saradnika nastalo je kao pokušaj identifikovanja osoba sklonih prihvatanju nacističke ideologije i jedno je od prvih istraživanja odnosa ličnosti i društvenih stavova (Milas, 2004). Autori su pokušali da pokažu da je sindrom stavova, nazvan antidemokratska orijentacija (što je svojevrsni sinonim za fašizam), koji čine antisemitizam, etnocentrizam (sa primesama rasizma) i političko-ekonomski konzervativizam, determinisan specifičnom osobinom ličnosti - autoritarnošću. U okviru svog istraživanja, berklijski autori razvili su skalu autoritarnosti i danas poznatu kao F skala. Sindrom autoritarne ličnosti zamišljen je kao višedimenzionalan, pa skala meri devet međusobno povezanih sklonosti koje ga determinišu: (1) konvencionalizam, (2) autoritarna submisivnost, (3) agresivnost, (4) antiintraceptivnost, (5) poštovanje vlasti i pozitivan odnos prema njoj, (6) destruktivnost i cinizam, (7) često korišćenje mehanizma projekcije, (8) rigidnost mišljenja praćena stereotipima i (9) preterano interesovanje za seksualne različitosti (Adorno, 1950, prema Rot, 1994).

Autori ove studije, kao i From, autoritarnost objašnjavaju oslanjajući se na psihoanalitičke koncepte. Koren autoritarnosti vidi se u porodici, odnosno u vaspitnom stilu koji karakterišu roditeljska strogost, nedoslednost i emocionalna hladnoća. Negativni porivi usmereni na roditelje se potiskuju i kasnije, mehanizmom projekcije, usmeravaju na eksterne objekte, najčešće manjinske ili ugrožene grupe. 
Najveći broj kritika upućenih berklijskoj grupi bio je usmeren na metodologiju istraživanja. Zamerke su se odnosile pre svega na visoko selekcionisani uzorak, jednosmernost stavki, pristrasnost procenjivača i nedostatak nekih ključnih kontrolnih varijabli (Rot, 1994). Uz to, ni psihoanalitički eksplanatorni okvir nije izbegao oštre kritike. Međutim, suštinski se kao najveći nedostatak ovog istraživanja ističe pridavanje prevelikog značaja osobinama ličnosti u formiranju socijalnih stavova, što je čitavo objašnjenje učinilo u velikoj meri psihologističkim (Jovančević, 2003).

Prvu ozbiljnu rekonceptualizaciju pojma autoritarnosti sproveo je Bob Altemejer. Cilj njegovog istraživanja bio je prvenstveno konstrukcija nove skale sa izbalansiranim stavkama i zadovoljavajućim metrijskim karakteristikama, ali i novo objašnjenje autoritarnosti koje bi zaobišlo psihoanalitičku teoriju (Petrović, 2001). Studija je rezultirala psihometrijski prihvatljivom skalom desničarske autoritarnosti (skraćeno RWA, od „right-wing authoritarianism“). Pri tome, termin "desničarska“ nema političku ili ekonomsku konotaciju, već se vezuje za postojeće, uspostavljene autoritete. Važno je istaći da se autoritarnost, u Altemejerovoj koncepciji, po prvi put ne shvata kao osobina ličnosti, već kao skup usklađenih stavova prema različitim pitanjima.

Pojam desničarske autoritarnosti obuhvatio je tri klastera stavova koji međusobno kovariraju: autoritarnu submisivnost - koja podrazumeva submisivnost prema uspostavljenim autoritetima određenog društva, autoritarnu agresivnost - koja se ispoljava kao opšta agresivnost prema objektima čije je sankcionisanje odobreno od strane autoriteta, i konvencionalizam - shvaćen kao privrženost konvencijama prihvaćenim od društva i autoriteta (Altemeyer, 1996).

Nastanak i razvoj autoritarnosti Altemejer objašnjava posredstvom Bandurine teorije socijalnog učenja. I ovde se uticaj roditelja smatra najsnažnijim (budući da je prvi, najtrajniji i najrelevantniji), ali važne uloge imaju i druge detetu bliske osobe, šira sredina, pa čak i mediji. Dakle, još jedna bitna odrednica Altemejerove teorije jeste da je autoritarnost karakteristika na koju se može uticati, odnosno koja se može menjati u toku života.

Ni Altemejerovo istraživanje nije bilo imuno na kritike. Među njima je svakako najznačajnija Ajzenkova, koja govori o zapostavljanju tzv. «levičarske» autoritarnosti; Altemejer se naknadno bavio ovim fenomenom, ali je negirao njegov značaj u današnjem svetu (Petrović, 2001).

Iako su, tokom višedecenijskih istraživanja, razvijeni brojni teorijski modeli i operacionalizacije autoritarnosti, neke od ključnih dilema (poput one o autoritarnosti kao osobini ličnosti ili sindromu stavova) još uvek nisu u potpunosti razjašnjene. Konceptualne nejasnoće i problemi merenja po svoj prilici su uti- 
cali na nastojanja da se utvrdi veza autoritarnosti sa drugim konstruktima, i to najčešće sa konzervativizmom, nacionalizmom, dogmatizmom i religioznošću. Pregledom studija koje su se bavile pomenutim konceptima, Ekhart (Eckhardt, 1991, prema Petrović, 2003) konstatuje da se radi o veoma srodnim fenomenima. Naime, iako se ne može govoriti o njihovoj identičnosti, postoji veliko prepokrivanje, te ih on smatra različitim aspektima jedinstvenog fenomena.

Posebno je važan koncept socijalne dominacije (Pratto, Sidanius, Stallworth, \& Malle, 1994), koji se odnosi na preferiranje društvene hijerarhije, nasuprot ravnopravnosti. Ova orijentacija, iako u niskoj korelaciji sa autoritarnošću, izuzetno je interesantna za političku psihologiju, jer je utvrđeno da osobe koje spadaju u najviši kvartil na obe dimenzije istovremeno, tzv. "dominirajući autoritarci”, ispoljavaju najvišu sklonost predrasudama (Altemeyer, 2004).

Raznolikost teorijskih pristupa i mnoštvo skala za procenu autoritarnosti i srodnih koncepata po svoj prilici utiču na probleme operacionalizacije ovog konstrukta u našoj kulturi. Kritike upućene $F$ skali tokom ranih faza njene primene (Rot i Havelka, 1973 prema Petrović, 2001) otklonjene su revizijom (Biro, Molnar i Popadić, 1997), a neke od verzija Altemejerove skale (Petrović, 2001; Altemeyer, 2003) uspešno su primenjivane kod nas. Situaciju, međutim, usložnjavaju rezultati nekih savremenih istraživanja, koji ukazuju da je autoritarnost istorijski "osetljiv" fenomen. Raden (1999) ističe da se antisemitizam, po Adornu neizostavni aspekt ovog koncepta, danas teško može smatrati sastavnim delom autoritarnog sindroma. Melon (Meloen, 1993, prema Petrović 2001) je utvrdio da se nivo autoritarnosti povećava u kriznim periodima, što ukazuje na situacionu uslovljenost ovog fenomena. Takođe, nalazi nekih studija potvrđuju da je nivo autoritarnosti pod uticajem spoljašnjih političkih i socijalnih pretnji (Feldman \& Stenner, 1997). Na istorijsku uslovljenost nivoa autoritarnosti ukazuju i rezultati istraživanja sprovedenog u Srbiji (Biro, Mihić, Milin i Logar-Đurić, 2002), koji sugerišu da je prosečna mera autoritarnosti građana Srbije opala već u roku od jedne godine u toku koje su se odigrale demokratske promene. Upravo osetljivost sadržaja konstrukta autoritarnosti na istorijska i društvena previranja nameće potrebu za konstrukcijom nove skale, osavremenjenog sadržaja, koja bi obuhvatila sve relevantne odlike autoritarnosti, a istovremeno bila prikladna za primenu na domaćem terenu, $\mathrm{u}$ aktuelnim okolnostima. 


\section{Studija 1}

\section{Problem i ciljevi}

Osnovni cilj ove studije je provera internih metrijskih karakteristika skale autoritarnosti UPA-S. Uvid u latentnu strukturu i merne karakteristike skupa indikatora autoritarnosti ima značajne praktične implikacije. Međutim, s obzirom na nedoumice u pogledu sadržaja konstrukta autoritarnosti, i probleme njegove konceptualizacije na domaćem terenu, potencijalni teorijski doprinos tretiranja ovog problema nije zanemarljiv (Martinović, Živanov i Mihić, 2008).

\section{Uzorak}

Istraživanje je sprovedeno na uzorku od 1198 ispitanika sa teritorije Vojvodine. Uzorkom je obuhvaćeno 546 muškaraca (46\% od ukupnog uzorka) i 642 žene (54\%). Starost ispitanika kretala se u rasponu od 18 do 69 godina, sa prosečnom starošću od 24 godine.

\section{Instrumenti}

U početni skup od 163 ajtema, namenjen konstrukciji instrumenta pod radnim nazivom UPA-S, uključene su stavke dve koncepcijski različite skale. Skala ADO (Čolović i sar., 2005 prema Drljača i Čolović, 2007) obuhvatala je indikatore devet karakteristika autoritarne ličnosti prema Adornu i saradnicima (Drljača i Čolović, 2007), dok je skala AUT-NS (Francesko, Mihic \& Kajon, 2006) bila zasnovana na socijalnopsihološkim konceptima autoritarnosti kao sindroma stavova. U prvu verziju instrumenta uključeno je 59 ajtema sa najboljim metrijskim svojstvima (Drljača i Čolović, 2007). Nakon preliminarne psihometrijske evaluacije 59-ajtemske verzije instrumenta (Martinović i sar., 2008) iz skale su isključene stavke koje nisu bile značajno zasićene nijednom od tri izolovane latentne dimenzije, kao i stavke čiji se sadržaj pokazao nerazumljivim ili redundantnim; tako je konačni skup čestica obuhvatio 47 ajtema sa Likertovim formatom odgovora.

\section{Rezultati i diskusija}

U cilju ispitivanja latentne strukture prostora merenja skale UPA-S, na matrici interkorelacija 47 stavki skale sprovedena je analiza glavnih komponenti. 
Ukupno 9 glavnih komponenti imalo je karakteristične korene veće od 1. Prema Scree kriterijumu (Grafik 1), izdvojene su tri glavne komponente, koje zajedno objašnjavaju 33,73\% ukupne varijanse (Tabela 1). Komponente su rotirane u Promax poziciju.

Tabela 1. Karakteristični koreni i procenat objašnjene varijanse

\begin{tabular}{ccccc}
\hline $\begin{array}{c}\text { Karakteristični } \\
\text { koren }\end{array}$ & $\begin{array}{c}\text { Procenat } \\
\text { varijanse }\end{array}$ & $\begin{array}{c}\text { Kumulativni } \\
\text { procenat }\end{array}$ & $\begin{array}{c}\text { Karakteristični } \\
\text { koren }\end{array}$ \\
\hline 1 & 10.277 & 21.865 & 21.865 & 8.308 \\
2 & 2.840 & 6.043 & 27.908 & 7.696 \\
3 & 2.735 & 5.819 & 33.727 & 5.623 \\
\hline
\end{tabular}

Scree Plot

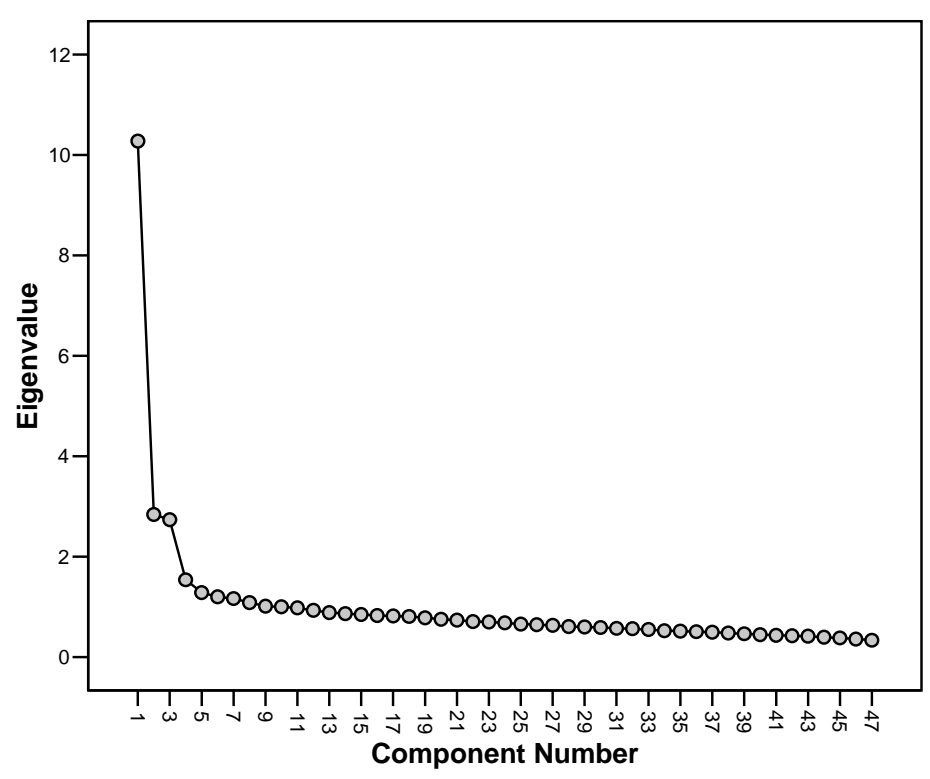

Grafik 1. Scree dijagram 
Tabela 2. Izvod iz matrica sklopa i strukture prve Promax komponente

\begin{tabular}{lccc}
\hline \multicolumn{1}{c}{ Ajtemi } & Sklop & Struktura & $\mathrm{h}^{2}$ \\
\hline $\begin{array}{l}\text { Nikada nećete pogrešiti ako uradite onako kako } \\
\text { vam kaže šef. }\end{array}$ & .744 & .714 & .519 \\
$\begin{array}{l}\text { Zakoni služe da bi se bezuslovno poštovali. } \\
\begin{array}{l}\text { Ko postupa po pravilima, ne mora da brine da li } \\
\text { je dobro postupio. }\end{array}\end{array}$ & .683 & .650 & .427 \\
$\begin{array}{l}\text { U nejasnoj situaciji jedino je ispravno postupati } \\
\text { onako kako ti šef kaže. }\end{array}$ & .663 & .673 & .469 \\
$\begin{array}{l}\text { Važno mi je da postoje pravila po kojima mogu } \\
\text { da se ponašam. }\end{array}$ & .626 & .589 & .402 \\
$\begin{array}{l}\text { Ako slušaš vlast, ne možeš pogrešiti. } \\
\text { Sve koji su protiv vlasti treba kažnjavati. }\end{array}$ & .605 & .581 & .365 \\
\begin{tabular}{l} 
Ne postoji situacija u kojoj bih ja prekršio zakon. \\
\hline
\end{tabular} & .562 & .535 & .337 \\
\hline
\end{tabular}

Stavke koje su u najvećoj meri zasićene prvom Promax komponentom odražavaju eksplicitnu sklonost ka potčinjavanju autoritetu, bez obzira da li je u pitanju pojedinac (rukovodilac), institucija (država) ili apstraktni princip (zakoni). Ovakva tendencija izražena je pre svega u formi stava, mada ima i indikatora njenih manifestacija na planu ponašanja. Budući da je sadržaj prve Promax komponente podudaran sa konceptom autoritarne submisivnosti, dimenzija je tako i imenovana.

Tabela 3. Izvod iz matrica sklopa $i$ strukture druge Promax komponente

\begin{tabular}{|c|c|c|c|}
\hline Ajtemi & Sklop & Struktura & $h^{2}$ \\
\hline Nema ništa gore od muškarca koji plače. & .700 & .651 & .441 \\
\hline $\begin{array}{l}\text { Odvratni su mi svi oni koji cmizdre pred drugi- } \\
\text { ma. }\end{array}$ & .693 & .661 & .485 \\
\hline $\begin{array}{l}\text { Homoseksualci, prostitutke i narkomani zaslu- } \\
\text { žuju da umru od SIDE. }\end{array}$ & .671 & .634 & .406 \\
\hline Prezirem ljude koji javno plaču. & .655 & .605 & .387 \\
\hline $\begin{array}{l}\text { Samoubice ne bi trebalo sahranjivati tamo gde } \\
\text { i normalne ljude. }\end{array}$ & .524 & .541 & .314 \\
\hline $\begin{array}{l}\text { Oni koji pričaju deci o kontracepciji podstiču ih } \\
\text { na nemoral. }\end{array}$ & .517 & .531 & .321 \\
\hline
\end{tabular}


Stavke koje okuplja druga Promax komponenta odnose se pre svega na averziju prema osobama i fenomenima koji se ne uklapaju u tradicionalni sistem vrednosti. Pored prezira prema marginalizovanim društvenim grupama, prisutna je intenzivna netrpeljivost prema javnom pokazivanju osećanja koja se mogu okarakterisati kao manifestacije slabosti. Upadljiva hostilnost usmerena prema društveno neprihvatljivim pojavama približava ovu dimenziju Altemejerovom konceptu desničarske agresivnosti. Stoga je druga Promax komponenta nazvana autoritarna agresivnost.

Tabela 4. Izvod iz matrica sklopa i strukture treće Promax komponente

\begin{tabular}{|c|c|c|c|}
\hline Ajtemi & Sklop & Struktura & $h^{2}$ \\
\hline $\begin{array}{l}\text { Čovek svaku životnu nedaću mora da podnese } \\
\text { uspravno i strpljivo. }\end{array}$ & .707 & .705 & .497 \\
\hline $\begin{array}{l}\text { Sve nevolje se mogu izdržati, ako si dovoljno } \\
\text { jak. }\end{array}$ & .703 & .635 & .426 \\
\hline $\begin{array}{l}\text { Čovek u životu mora stojati uspravno i ne do- } \\
\text { pustiti da ga išta uzdrma. }\end{array}$ & .692 & .706 & .501 \\
\hline Moj moto je "Samo najjači opstaju". & .502 & .543 & .305 \\
\hline $\begin{array}{l}\text { Porodični problemi moraju ostati u krugu po- } \\
\text { rodice. }\end{array}$ & .348 & .474 & .305 \\
\hline
\end{tabular}

Sadržaj stavki koje značajno doprinose sklopu i strukturi treće Promax komponente odražava percepciju sveta kao opasnog mesta gde stoičko podnošenje nevolja predstavlja najbolju strategiju preživljavanja, a snaga i čvrstina zauzimaju visoko mesto u hijerarhiji vrednosti. Faktor je, s obzirom na istovremeno prisustvo markera „čvrste naravi“ i visokog vrednovanja izdržljivosti i snage, imenovan kao stoicizam.

Svi koeficijenti korelacije između Promax komponenti statistički su značajni na nivou $\mathrm{p}<0,001$. Najviši je koeficijent korelacije između Autoritarne submisivnosti i Autoritarne agresivnosti $(\mathrm{r}=0,479)$. Koeficijent korelacije između Stoicizma i Autoritarne submisivnosti iznosi 0,352, a između Stoicizma i Autoritarne agresivnosti 0,343. Dimenzionalnost prostora drugog reda ispitana je analizom glavnih komponenti, sprovedenom na matrici interkorelacija faktorskih skorova na Promax dimenzijama. Izolovana je jedna glavna komponenta značajna prema Gutman- Kajzerovom kriterijumu $(\lambda=1,785)$, koja objašnjava $59,514 \%$ varijanse komponenti prvog reda. Sve primarne Promax dimenzije visoko su zasićene glavnom komponentom drugog reda, pri čemu su zasićenja ujednačene visine. 
Tabela 5.Struktura glavne komponente drugog reda u prostoru merenja skale UPA-S

\begin{tabular}{cc}
\hline & $r$ \\
\hline Autoritarna submisivnost & .804 \\
Autoritarna agresivnost & .799 \\
Stoicizam & .708 \\
\hline
\end{tabular}

Intenzitet povezanosti među dimenzijama prvog reda, i struktura glavne komponente izolovane na drugom nivou hijerarhije, govore $u$ prilog egzistencije autoritarnosti kao jedinstvenog konstrukta.

U svrhu utvrđivanja metrijskih karakteristika skale korišćen je makro program za procenu metrijskih karakteristika kompozitnih mernih instrumenata RTT9G, verzija 2,3 (Knežević i Momirović, 1996), sa modifikacijama koje je 2000. godine sproveo Stanislav Fajgelj.

Tabela 6.Indikatori pouzdanosti, reprezentativnosti i homogenosti skala instrumenta UPA-S

\begin{tabular}{lcccccc}
\hline & $\mathrm{a}^{1}$ & $\beta^{2}$ & $\mathrm{MSA}^{3}$ & $\mathrm{H} 1^{4}$ & $\mathrm{H} 2^{5}$ & $\mathrm{~N}$ \\
\hline Autoritarna submisivnost & 0.8858 & 0.8874 & 0.9193 & 0.2899 & 0.7951 & 19 \\
Autoritarna agresivnost & 0.8553 & 0.8584 & 0.9022 & 0.2372 & 0.7808 & 19 \\
Stoicizam & 0.7675 & 0.7741 & 0.8464 & 0.2684 & 0.8770 & 9 \\
Autoritarnost & 0.9198 & 0.9220 & 0.9299 & 0.1962 & 0.5638 & 47 \\
\hline
\end{tabular}

${ }^{1}$ Cronbach - koeficijent pouzdanosti (tip interne konzistencije); ${ }^{2}$ Lord - Kaiser - Caffrey- koeficijent pouzdanosti prve glavne komponente; ${ }^{3}$ normalizovani Kajzer - Majer - Olkinov koeficijent reprezentativnosti; ${ }^{4}$ prosečna interkorelacija stavki; ${ }^{5}$ Momirović - relativna veličina varijanse prve glavne imaž komponente

Skala UPA-S i njene supskale imaju zadovoljavajuću pouzdanost, reprezentativnost i homogenost. Nešto niža homogenost skale u celini bila je očekivana, dok su skale Autoritarna submisivnost i Autoritarna agresivnost zadovoljavajućeg psihometrijskog kvaliteta. Nešto slabijim mernim svojstvima izdvaja se skala Stoicizam; međutim, s obzirom na mali broj stavki, i njene metrijske karakteristike se, prema blažem kriterijumu, mogu smatrati prihvatljivim.

Rezultati komponentne analize prostora merenja skale UPA-S sugerišu da je autoritarnost višedimenzionalan konstrukt, čiji latentni prostor prvog reda konstituišu tri dimenzije - Autoritarna submisivnost, Autoritarna agresivnost i Stoicizam - obuhvaćene jedinstvenom latentnom dimenzijom drugog reda. Dimenzije prvog reda okupljaju širok spektar indikatora autoritarnosti. Izvesno odstupanje od dosadašnjih nalaza (Altemeyer, 1996; Rot, 1994) predstavlja ekstrakcija Stoicizma kao posebne dimenzije. Ovakav rezultat može se donekle pripisati specifičnostima naše sredine, i u tom kontekstu svedoči u prilog 
teze o uticaju istorijskih, kulturnih i političkih faktora na sadržaj autoritarnosti (Feldman \& Stenner, 1997; Biro i sar., 2002). Međutim, dimenzija Stoicizam može se razmatrati i u svetlu debate koja suprotstavlja autoritarnost kao sindrom stavova autoritarnosti shvaćenoj kao osobina ličnosti. Naime, tvrdnje „stavskog" formata, koje najviše doprinose sadržaju ove dimenzije, po svoj prilici reflektuju stabilnu dimenziju ličnosti koja je u ranijim studijama imenovana kao „čvrsta narav“ (tough-mindedness). Priroda ove dimenzije ne može se jednoznačno odrediti: identifikovana kao jedna od determinanti socijalnih stavova (Ray, 1986), ona je, u prostoru Ajzenkovog modela, pripisana domenu Psihoticizma (Eysenck \& Wilson, 1978 prema Ray, 1981). Moguće je da i Stoicizam na sličan način odražava dualnu prirodu nekih modaliteta autoritarnosti: reč je o dispoziciji koja, čini se, podrazumeva interakciju stavova i stabilnih karakteristika ličnosti.

\section{Studija 2}

\section{Problem i cilj istraživanja}

Osnovni cilj ove studije je utvrđivanje konstruktne, odnosno konvergentne validnosti skale UPA-S. Utvrđivanje povezanosti između skala UPA-S i mera autoritarnosti i srodnih konstrukata, pored provere metrijskog kvaliteta instrumenta, omogućava dalji uvid u prirodu koncepta autoritarnosti.

\section{Uzorak}

Istraživanjem je obuhvaćen uzorak od 649 ispitanika sa teritorije Vojvodine, oba pola (284 muškarca (43.8\%) i 365 (56.2\%) žena), starosti od 18 do 67 godina, prosečne starosti 33 godine.

\section{Instrumenti}

Pored skale UPA-S, u ovoj studiji primenjene su dve skale za procenu autoritarnosti - Skala desničarske autoritarnosti (RWA; Altemeyer, 2003), i beogradska revizija F skale (FBG; Biro i sar., 1997), kao i dve skale namenjene proceni konstrukata srodnih autoritarnosti - Skala socijalne dominacije (SDO; Pratto i sar., 1994), i adaptirana verzija Skale modernog rasizma (SMR; McConahay, 1986). U analizama su korišćeni sumacioni skorovi na skalama (Tabela 7). 


\section{Rezultati}

Deskriptivni statistički pokazatelji i Kronbahovi $\alpha$ koeficijenti pouzdanosti skala prikazani su u Tabeli 7.

Tabela 7. Deskriptivni statistički pokazatelji i pouzdanost instrumenata

\begin{tabular}{lrrrrrrrr}
\hline & N & AS & Min. & Maks. & SD & Sk & Ku & a \\
\hline SMR & 7 & 20.536 & 7.000 & 35.000 & 6.010 & 0.017 & -0.245 & 0.816 \\
SDO & 16 & 37.929 & 16.000 & 79.000 & 9.436 & 0.106 & -0.031 & 0.769 \\
RWA & 20 & 55.912 & 20.000 & 84.000 & 11.542 & -0.362 & -0.195 & 0.812 \\
FBG & 12 & 32.507 & 12.000 & 60.000 & 9.615 & -0.064 & -0.503 & 0.868 \\
SUB & 19 & 45.613 & 19.000 & 95.000 & 13.887 & 0.323 & -0.073 & 0.906 \\
AGR & 19 & 40.884 & 19.000 & 94.000 & 13.033 & 0.749 & 0.563 & 0.876 \\
STO & 9 & 33.180 & 9.000 & 45.000 & 6.776 & -0.555 & 0.192 & 0.8 \\
UPAS & 47 & 119.677 & 47.000 & 234.000 & 28.891 & 0.220 & 0.085 & 0.937 \\
\hline
\end{tabular}

Legenda: SMR- Skala modernog rasizma; SDO- Skala socijalne dominacije; RWA- Skala desničarske autoritarnosti; FBG- Beogradska revizija F skale; SUB- Autoritarna submisivnost (UPA-S); AGR- Autoritarna agresivnost (UPA-S); STO- Stoicizam (UPA-S); UPAS- Ukupni skor na skali UPA-S; Sk - zakrivljenost (Skewness); Ku - zaravnjenost (Kurtosis); a - Kronbahova alfa

Vrednosti Kronbahovih alfa koeficijenata pouzdanosti (Tabela 7) prihvatljive su prema konvencionalnom kriterijumu, pri čemu je jedino Kronbahova alfa Skale socijalne dominacije niža od 0,8 . Vrednosti pokazatelja zakrivljenosti i spljoštenosti kreću se u granicama prihvatljivog.

Uvid $\mathrm{u}$ poziciju dimenzija UPA-S u prostoru mera autoritarnosti i srodnih konstrukata ostvaren je primenom konfirmativne faktorske analize. Analiza je sprovedena na matrici interkorelacija sumacionih skorova na supskalama UPA-S, FBG, RWA, SDO i SMR. Metod za procenu parametara bio je kombinovani metod generalizovanih najmanjih kvadrata i maksimalne verodostojnosti, a za procenu fita modela korišćeni su hi-kvadrat, komparativni indeks fita (CFI), koren prosečne kvadrirane greške aproksimacije (RMSEA), koren iz kvadriranih standardizovanih reziduala (RMSSR) i GFI indeks Jereskoga i Serboma (Kline, 2005).

Isprobana su tri hipotetska modela. Modelom 1 predviđeno je postojanje jedne latentne dimenzije na najvišem nivou hijerarhije. Ova dimenzija, pored skorova na skalama SDO, SMR, RWA i FBG, obuhvata i latentnu dimenziju nižeg reda koja zasićuje dimenzije iz prostora skale UPA-S. Modelom 2 pretpostavljeno je postojanje dve međusobno korelirane dimenzije najvišeg stratuma. Prvom su obuhvaćeni skorovi na skalama autoritarnosti, odnosno FBG i 
RWA, kao i latentna varijabla kojom su zasićene dimenzije UPA-S. Drugoj latentnoj dimenziji pripisani su konstrukti srodni, ali ne ekvivalentni, autoritarnosti, odnosno skorovi na skalama SDO i SMR. U Modelu 3, latentna dimenzija nižeg reda iz prostora UPA-S ravnopravno pripada domenima prve i druge latentne dimenzije.

Tabela 9. Pokazatelji fita modela

\begin{tabular}{cccccccc}
\hline & $\mathrm{X}^{2}$ & $\mathrm{df}$ & $\mathrm{p}$ & $\mathrm{GFI}$ & $\mathrm{CFI}$ & $\mathrm{RMSEA}$ & $\mathrm{RMSSR}$ \\
\hline Model 1 & 98.370 & 13.000 & 0.000 & 0.956 & 0.954 & 0.104 & 0.046 \\
Model 2 & 66.497 & 12.000 & 0.000 & 0.971 & 0.971 & 0.085 & 0.033 \\
Model 3 & 66.489 & 11.000 & 0.000 & 0.971 & 0.970 & 0.090 & 0.033 \\
\hline
\end{tabular}

Legenda: $\chi^{2}$ - hi-kvadrat test; $\mathrm{df}$ - broj stepeni slobode; $\mathrm{p}$ - nivo značajnosti; GFI - „Goodnesof-fit“ indeks (prihvatliive vrednosti iznad 0,9); CFI - komparativni indeks fita (prihvatljive vrednosti iznad 0,9); RMSEA - koren prosečne kvadrirane greške aproksimacije (prihvatliive vrednosti ispod 0,1); RMSSR - koren iz proseka kvadriranih standardizovanih reziduala (prihvatljive vrednosti ispod 0,08 )

Iako pokazatelji fita načelno sugerišu prihvatljivost svih modela (izuzev RMSEA indeksa u prvom modelu, čija je vrednost viša od dozvoljene gornje granice), primetno je da je fit trećeg modela nešto slabiji od fita Modela 2. Budući da je opterećenje faktora iz prostora UPA-S drugom latentnom dimenzijom (koja obuhvata konstrukte srodne, ali ne ekvivalentne autoritarnosti), bilo praktično jednako nuli $(\lambda=-0,007 ; \mathrm{p}>0,1)$, kao najadekvatniji je prihvaćen jednostavniji Model 2.

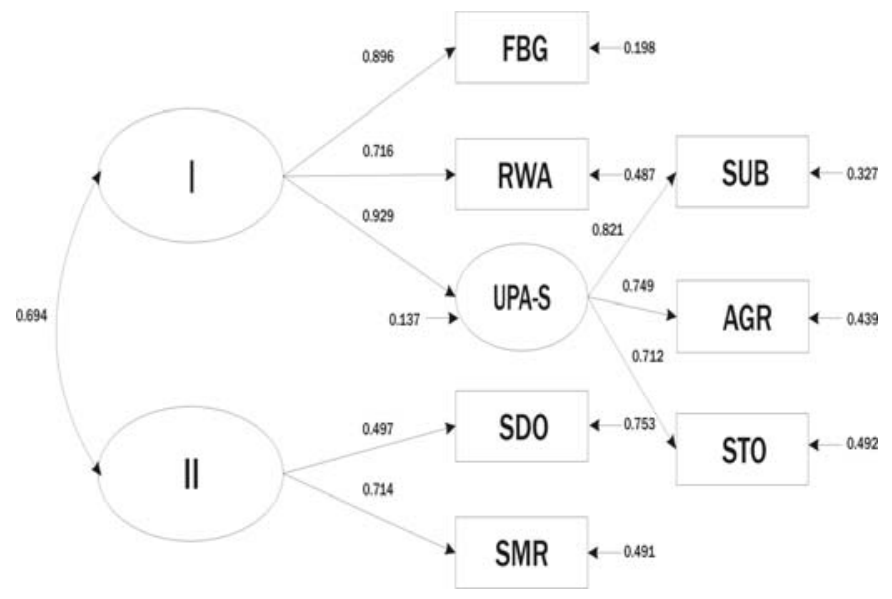

Grafik 2. Procena parametara modela 2 
Legenda: SMR- Skala modernog rasizma; SDO- Skala socijalne dominacije; RWA- Skala desničarske autoritarnosti; FBG- Beogradska revizija F skale; SUB- Autoritarna submisivnost (UPAS); AGR- Autoritarna agresivnost (UPA-S); STO- Stoicizam (UPA-S)

Dimenzija iz prostora UPA-S i skorovi na skalama FBG i RWA imaju visoka zasićenja na prvoj latentnoj dimenziji, koja se može okarakterisati kao generalni faktor autoritarnosti. Pri tome, opterećenje Altemejerove skale prvom latentnom dimenzijom, iako visoko, nešto je niže od opterećenja dimenzija FBG i UPA-S, koja su ujednačene visine. Druga dimenzija obuhvata skorove na skalama SMR i SDO, pri čemu je opterećenje skora na Skali modernog rasizma nešto više. Korelacija između dimenzija najvišeg hijerarhijskog nivoa je visoka. Stoga se može reći da su skale UPA-S, uprkos nedvosmislenoj pripadnosti domenu autoritarnosti, posredno povezane sa konceptima poput socijalne dominacije i rasizma, što je u skladu sa nalazima prethodnih studija (Eckhardt, 1991 prema Petrović, 2003).

\section{Generalna diskusija}

Osnovni cilj ovog istraživanja bio je provera nove skale autoritarnosti, konstruisane sa idejom da se objedine indikatori dve dominantne koncepcije autoritarnosti. Prostor merenja skale UPA-S čine tri faktora (autoritarna submisivnost, autoritarna agresivnost i stoicizam) koji se faktorskom analizom drugog reda mogu svesti na jednu dimenziju višeg reda. Ovakvi rezultati idu u prilog teorijskim i empirijskim modelima koji naglašavaju kompleksnost fenomena autoritarnosti (Altemeyer, 1996).

Sadržaj komponente imenovane kao Autoritarna submisivnost, zasićen dogmatizmom i bespogovornim poverenjem $u$ autoritet, odgovara tradicionalnim shvatanjima prirode autoritarnog potčinjavanja. Stavke koje su u najvećoj meri povezane sa drugom dimenzijom karakteriše izrazit latentni agresivni naboj usmeren ka pojavama koje se smatraju devijantnim; stoga je ova dimenzija interpretirana kao autoritarna agresivnost. Međutim, u njenom sadržaju mogu se prepoznati indikatori nekih modaliteta autoritarnosti koji se u ovom istraživanju nisu izdvojili kao posebne dimenzije, poput antiintraceptivnosti ili konzervativizma. Čini se da, u ovom kontekstu, konkretni fenomeni, poput ispoljavanja slabosti ili neprihvatljivog životnog stila, predstavljaju tek objekte ka kojima se usmerava „politički korektno“ neprijateljstvo. Treća Promax komponenta, koja obuhvata indikatore čvrste naravi i visokog vrednovanja snage, uz prihvatanje agresivnosti kao egzistencijalnog načela („život je neprekidna borba"), nije u tom obliku registrovana u ranijim studijama autoritarno- 
sti. Ovakav podatak, po svoj prilici, odražava podložnost sadržaja koncepta autoritarnosti promenama usled društvenih i istorijskih kretanja, i opravdava pokušaj nove operacionalizacije. Imajući u vidu interpretabilnost Promax dimenzija i dobre metrijske karakteristike skala formiranih na temelju ovog faktorskog rešenja, može se konstatovati da skala UPA-S predstavlja zadovoljavajuću operacionalizaciju konstrukta autoritarnosti.

Drugi segment istraživanja bio je usmeren na proveru odnosa između autoritarnosti merene skalom UPA-S i drugih skala autoritarnosti, kao i koncepata bliskih pojmu autoritarnosti. Rezultati pokazuju da je najprihvatljiviji model po kome se izdvajaju dve latentne dimenzije. Prva je zasićena skorovima na sve tri skale autoritarnosti (UPA-S, Beogradska revizija Adornove skale i skala desničarske autoritarnosti), kao i skorovima na sve tri dimenzije skale UPA-S. Druga latentna dimenzija zasićena je konceptima bliskim autoritarnosti (orijentacija ka socijalnoj dominaciji i moderni rasizam). Ovakvi rezultati govore u prilog teze o srodnosti, ali ne i identičnosti, autoritarnosti i koncepata poput rasizma ili orijentacije ka socijalnoj dominaciji (Eckhardt, 1991 prema Petrović, 2003).

Međutim, jedno od ključnih pitanja vezanih za prirodu konstrukta autoritarnosti i dalje ostaje otvoreno; reč je o podvojenosti između shvatanja autoritarnosti kao osobine ličnosti, odnosno sindroma stavova. Visoko zasićenje dimenzije UPA-S faktorom koji istovremeno obuhvata reviziju F skale (koncepciju bližu shvatanju autoritarnosti kao osobine ličnosti) i Altemejerovu skalu desničarske autoritarnosti (koja je, prema deklaraciji autora, pretežno „stavski“ orijentisana), ne omogućava jednostavan odgovor. Istraživanja usmerena na utvrđivanje povezanosti dimenzija UPA-S i osobina ličnosti (što se odnosi kako na modele ličnosti, tako i na specifične konstrukte) svakako bi obezbedila korisne informacije; međutim, na temelju dosadašnjih nalaza, mogućnost jednoznačnog određenja prirode autoritarnosti ne čini se izvesnom. U ovom trenutku, istini je, po svoj prilici, najbliža konstatacija da struktura UPA-S, u skladu s prvobitnim namerama autora, odražava dualnu prirodu autoritarnosti; klasteri stavova povezani su sa specifičnim obrascima ponašanja, pa i emocionalnog reagovanja, formirajući koherentne dimenzije individualnih razlika. 


\section{Literatura}

Adorno, T. W., Frenkel-Brunswik, E., Levinson, D. J., \& Sanford, R. N. (1950). The Authoritarian Personality. New York: Harper \& Row.

Altemeyer, B. (1996). Authoritarian Specter. Cambridge \&. London: Harvard University Press.

Altemeyer, B. (2003). What Happens When Authoritarians Inherit the Earth? A Simulation. Analyses of Social Issues and Public Policy,3, 161-169.

Altemeyer, B. (2004). Highly Dominating, Highly Authoritaritarian Personalities. The Journal of Social Psychology, 144, 421-447.

Biro, M., Mihić, V., Milin, P., i Logar, S. (2002). Did Socio-Political Changes in Serbia Changed the Level of Authoritarianism and Ethnocentrism of Citizens? Psihologija, 35, 37-47.

Biro, M., Molnar, A., i Popadić, D. (1997). Stavovi građana Srbije prema pravnoj državi: relacija sa obrazovanjem, autoritarnošću i poznavanjem ljudskih prava. Sociologija, 2, 168-182.

Drljača, D., i Čolović, P. (2007). Relacije dimenzija Alternativnog petofaktorskog modela ličnosti i autoritarnosti. Saopštenje na XIII naučnom skupu Empirijska istraživanja u psihologiji, knjiga rezimea, 75.

Feldman, S., \& Stenner, K. (1997). Percieved Threat and Authoritarianism. Political Psychology, 18, 741-769.

Francesko, M., Mihic, V. \& Kajon, J. (2006). The authoritarian personality re-consideration in the new context. Saopštenje na Annual meeting of the International Society of Political Psychology (Barcelona 12-15. jul). Book of abstracts on CD.

Fromm, E. (1989). Bekstvo od slobode. Zagreb: Naprijed.

Jovančević, S. (2003). Autoritarnost kao elemenat društvenog karaktera i činilac društvene interakcije polova. Filozofija i društvo, 22-23, 171-194.

Kline, R. B. (2005). Principles and practise of structural equation modeling. New York: Guilford Press.

Martinović, M. , Živanov, S., i Mihić, V. (2008). Povezanost autoritarnosti sa nekim sociodemografskim varijablama kod stanovnika Vojvodine. Saopštenje na 56. Naučno-stručnom skupu psihologa Srbije, knjiga rezimea, 45.

McConahay, J. B. (1986). Modern Racism, Ambivalence, and the Modern Racism Scale. In: J. F. Dovidio \& S. L. Gaertner (Eds.), Prejudice, discrimination, and racism (pp. 91-125). Orlando: Academic Press.

Milas, G. (2004). Ličnost i društveni stavovi. Jastrebarsko: Naklada Slap.

Petrović, N. (2001). Specifikacija elemenata autoritarnosti u modelu Boba Altemejera. Psihologija, 34, 169-194. 
Petrović, N. (2003). Pregled pristupa za izučavanje autoritarnosti i srodnih fenomena. Sociološki pregled, 37, 101-115.

Pratto, F., Sidanius, J., Stallworth, L. M., \& Malle, B. F. (1994). Social Dominance Orientation: A personality variable predicting social and political attitudes. Journal of Personality and Social Psychology, 67, 741-763.

Raden, D. (1999). Is Anti-Semitism Currently Part of an Authoritarian Attitude Syndrome? Political Psychology, 20.

Ray, J., \& Bozek, R. S. (1981). Authoritarianism and Eysenck's P scale. The Journal of Social Psychology, 113, 231 - 234.

Ray, J. (1986). Eysenck on social attitudes: an historical critique. In S. Modgil, C.M. Modgil (Eds.) Hans Eysenck: Consensus and Controversy (pp. 155 173). Lewes: Falmer.

Rot, N. (1994). Osnovi socijalne psihologije. Beograd: Zavod za udžbenike i nastavna sredstva. 


\title{
ABSTRACT
}

\section{LATENT STRUCTURE AND CONVERGENT VALIDITY OF A NEW AUTHORITARIANISM SCALE}

\author{
Vladimir Mihic, Bojana Bodroza, \& Petar Colovic
}

Two studies, aimed at the assessment of internal psychometric properties and construct validity of the new authoritarianism scale, UPA-S, are presented in the paper. The UPA-S scale contains 47 items originating from two earlier authoritarianism scales- ADO (regarding authoritarianism as a personality trait) and AUT-NS (considering authoritarianism as an attitude syndrome). The main aim of the Study 1 was the assessment of internal psychometric properties of the UPA-S scale. Applying the principal component analysis with Promax rotation, three latent dimensions were extracted and interpreted as authoritarian submissiveness, authoritarian aggressiveness and stoicism. The reliability, homogeneity and representativeness indices of the three resulting scales of the UPA-S were satisfactory. Convergent validity of the UPA$S$ was examined in Study 2. By means of confirmatory factor analysis, three models (involving UPA-S scales, Altemeyer's RWA, Revised F scale, Social Dominance Scale and Modern Racism Scale) were tested. The best- fitting model consisted of two correlated latent dimensions, the first one including authoritarianism scales, and the second one including the measures of related constructs. The results suggest that the psychometric properties of the UPA-S are satisfactory, and at the same time support the views which regard authoritarianism as a multi-dimensional construct which consists of both specific attitudes and personality characteristics.

Key words: authoritarianism, social domination, racism, F scale. 